\title{
Autologous platelet rich plasma enhances satellite cells expression of MyoD and exerts angiogenic and antifibrotic effects in experimental rat model of traumatic skeletal muscle injury
}

\section{Original Article}

Ghalia Mahfouz Attia ${ }^{1,2}$, Hoda Atef ${ }^{1}$, and Rasha Ahmed Elmansy ${ }^{3}$

\author{
${ }^{I}$ Department of Histology and Cell Biology, Faculty of Medicine, Mansoura University, \\ Mansoura, Egypt
}

${ }^{2}$ Department of Anatomy, Faculty of Medicine, Taibahu University, Al Madina Al Monawarrah, KSA

${ }^{3}$ Department of Anatomy and Embryology, Faculty of Medicine, Ain Shams University, Cairo, Egypt

\begin{abstract}
Introduction: Skeletal muscle injuries comprise the greater part of sports-related injuries. Role of growth factors in healing of injured tissue encouraged the use of platelet-rich plasma (PRP).

Aim of the work: We aimed to study the effect of PRP on skeletal muscle injury.

Materials \& Methods: Forty adult male rats were divided into four equal groups; control and 2, 7, 14 days after the injury. The injured muscles were either treated with PRP or left without treatment. The rats were sacrificed and the muscle specimens were processed for histological and immunohistochemical staining for detection of Anti-MyoD, anti-CD34 and anti TGF $\beta 1$ followed by morphometric study.

Results: PRP treatment induced initial intense inflammatory response with neutrophils and macrophages cell infiltrate subsided in the 7th day. When compared to untreated groups, PRP treated ones showed significant increases in the mean number of regenerating muscle fibers $(22.03 \pm 4.08)$ and angiogenesis $(10.83 \pm 2.46)$ on the 7 th day. The median number of MyoD immunopositive stellate cells showed a significant increase on the 2nd day,72 (62-78) and then decrease on the 7th day; 28(22-33) to be non significant after 14th days; 4(3-5) of injury. A significant decrease in the mean area \% of collagen deposition $(2.27 \pm .0 .59,3.68 \pm 0.72$ and $4.76 \pm 0.82)$ and TGF $\beta 1$ immunoexpression, medians; 5 (4.20-5.70), 2.50 (2.10-3.50) and 2.30( 1.60-3.20) after 2, 7 and 14 days, respectively, were observed.

Conclusions: PRP could exert a promising effect on skeletal muscle injuries via enhancing myogenesis, neovascularization and reduction of fibrosis. Since autologous blood preparations are safe, PRP may serve as a valuable adjunct in management of such injuries.
\end{abstract}

Key Words: CD34, MyoD, Platelets rich plasma, Satellite cells, Skeletal muscle Injury, TGF $\beta 1$

Revised: 21 April 2017, Accepted: 21 September 2017

Corresponding Author: Ghalia M,Attia, Department of Histology and Cell Biology, Faculty of Medicine, Mansoura University, Mansoura, Egypt, Tel.: 00966534397724, E-mail: drghalia2011@gmail.com

ISSN: 1110-0559, Vol. 40, No. 4

\section{INTRODUCTION}

Skeletal muscle injuries comprise the greater part of sports-related injuries disturbing hundreds of millions of people around the world ${ }^{[1,2]}$ that may have an effect on the ability to exercise leading to high tendency of recurrence especially among athletes ${ }^{[3,4]}$. A variety of mechanisms can cause these injuries including lacerations, contusions, and strains $^{[5]}$ as well as medical states such as ischemia and neurologic dysfunction ${ }^{[6.7]}$. Injured muscles go through a characteristic set of overlapping phases that consist of degeneration, inflammation, regeneration and finally fibrosis ${ }^{[8,9]}$. Balance between pro-inflammatory and antiinflammatory factors can affect muscle regeneration and determine whether muscle damage will be resolved with either muscle fiber replacement and restoring its contractile function or end with scar tissue formation ${ }^{[10]}$. Conservative therapy including ice application, compression, elevation and rest are often insufficient. Thus, a considerable attention is generated for the use of promising methods to decrease inflammation and pain, prevent muscle fibrosis, enhance soft-tissue healing and reduce the time needed for recovery.

All of the phases of muscle injury are controlled by compound and active molecular mechanisms involving local and systemic factors that interact with a lot of cell types recruited to the wound site ${ }^{[11,12]}$. Satellite cells (SCs) are the main myogenic stem cells which are located between the myofiber sarcolemma and the basal lamina and when these satellite cells are stimulated by muscle damage they start to proliferate and blend with the existing muscle fibers or combine together forming new ones. This unique capacity of SCs makes them the "motor" of skeletal 
muscle regeneration ${ }^{[13.14]}$. Satellite cells are quiescent in resting adult muscles and express a paired box protein called Pax7. When they are stimulated during growth or muscle injury, they are activated and express the myogenic regulatory factors Myf5 and/or MyoD.

The MyoD (myoblast marker) is an important myogenic regulatory factor that acts as transcription regulatory protein via binding to numerous muscle-specific genes. Its expression is extremely increased in activated satellite cells after injury and is commonly regarded as a marker of activated satellite cells ${ }^{[15]}$. Also, MyoD and myogenin play a major role during embryonic and neonatal myogenesis ${ }^{[16,}$ 17]. Transforming growth factors-beta (TGF $\beta$ s) are a small family of growth factors, comprising of TGF $\beta 1, \beta 2$ and $\beta 3$. All these growth factors have the general feature of their ability to bind to extracellular proteins and are stored in the extracellular matrix until their activation by a physiological process such as wound healing. Breakdown of platelets at the site of injury causes the release TGF $\beta 1$ and the resident smooth myogenic cells continue to produce it .Over production of TGF $\beta 1$ as in case of persistent inflammation results in more ECM deposition at the site of injury leading to fibrosis ${ }^{[12]}$.

Throughout the last years, the great appreciation of the role of growth factors in the healing of injured tissue encouraged the use of platelet-rich plasma (PRP) in soft and hard connective tissue healing and repair. PRP simply refers to the presence of a very large number of platelets in a small volume of plasma, at least in a concentration of $1,000,000$ platelets $/ \mu \mathrm{L}$, which results in an increase in growth factors concentration up to 3 to 5 folds. Nowadays, PRP is considered as a new promising curative tool in the field of acute trauma, cardiac muscle injuries, nerve injuries, dermatology, dentistry, chronic tendinopathies, cosmetic surgery and veterinary medicine ${ }^{[18-22]}$ but its efficacy as a treatment for musculoskeletal soft-tissue injuries is still unconfirmed. Platelets are recognized to contain a variety of factors concerned in the repair of vasculature and tissues. One of the identified platelet secretory granules are alpha granules that contain plateletderived growth factor (PDGF), transforming growth factorbeta (TGFB), epidermal growth factor (EGF), vascular endothelial growth factor(VEGF), cytokines and others ${ }^{[23]}$. This knowledge stimulated the development of a platelet concentrate intended for increasing levels of local growth factors (GFs) delivery at the injury site to improve tissue repair, regeneration and remodeling ${ }^{[24,25]}$.Therefore, the present study was conducted to elucidate the morphometric and histological changes after local application of PRP in induced traumatic skeletal muscle injury in rats in a trial to describe the efficacy of PRP in the treatment of such cases.

\section{PATIENTS AND METHODS}

\section{Animals}

Forty 4-months-old male albino rats (200-250 gm) were purchased from the animal house,
Faculty of Medicine, Mansoura University. The animals were maintained under conventional relative humidity, 12-h light/12-h dark, and allowed free access to chow and water. All steps of experiment were done according to the regulations of "Institutional Research Board (IRB)" for Animal Experimentation, Faculty of Medicine, Mansoura University. After one week of acclimatization the animals were divided into 2 groups as follows:

1- Control group (10 rats) were left uninjured

2- Experimental group (30 rats): Muscle injury was induced in the anterior limb flexor muscles (Right and left limbs). Left limbs of all groups were left without treatment, whereas right limbs were treated with PRP. This group was further subdivided into 3 subgroups:

A. 2days group (10 rats): Specimens were taken after 2 days and were subdivided into:

\section{untreated group and-PRP treated group}

B. 7 days group (10 rats): Specimens were taken after 7 days and were subdivided into:

untreated group andPRP treated group.

C. 14 days group (10 rats): Specimens were taken after 14 days and were subdivided into untreated group and PRP treated.

\section{Induction of muscle and skin injury}

Under general anaesthesia, muscle and skin injuries were induced by intramuscular injection of tiletamine and zolazepam (Zoletil) $3 \mathrm{mg} / \mathrm{k}^{[26]}$. After hair shaving, a longitudinal incision was done in the skin of both left and right anterior limbs from the elbow to the wrist to expose the flexor sublimis muscles of the upper joint of the digits. This was followed by induction of flexor muscles injury of both anterior limbs transversely and then medially by a scalpel. A wedge-shaped wound $4 \mathrm{~mm}$ long, $3 \mathrm{~mm}$ wide and $3 \mathrm{~mm}$ deep was done. The injury sites of right limb muscles of the treated animals were immediately filled with PRP whereas those of the left limb muscles were left without treatment and the skin wounds of both limbs was sutured (Fig.1).

\section{Blood collection and preparation of platelet-rich plasma}

Blood samples were obtained by retro-orbital method ${ }^{[27]}$. These samples were collected immediately before the surgical induction of injury to the muscle. About 3-3.5 ml Blood was withdrawn slowly from each rat into a syringe containing $1 \mathrm{~mL}$ of $3.8 \%$ sodium citrate. For preparation of $\mathrm{PRP}^{[26]}$, blood was transferred into sterile tubes containing sodium citrate and underwent two centrifugations. The first centrifugation was done at $220 \mathrm{~g}$ for 15 minutes. The small amount of plasma layer obtained underwent complete blood count for checking the presence of other blood cells and the number of platelets. A second centrifugation was 
done at $2000 \mathrm{~g}$ for 5 minutes which made the platelets fall down into the bottom of the tubes. The obtained platelets were re- suspended in about $100 \mu \mathrm{L}$ plasma. This platelet rich plasma was activated by addition of $20 \mu \mathrm{L}$ of $10 \%$ calcium chloride at $37^{\circ} \mathrm{C}$. After jellification, the obtained pellet was immediately put into the site of muscle injury of the same animal of which blood sample was taken. The wound was then sutured and washed with saline solution (Fig. 1).

Figure 1. A photograph shows the steps of induction of muscle injury and PRP preparation: A) Surgical instruments. B) Retro-orbital blood collection. C) Centrifugation of blood samples. D) PRP-in the top layer after centrifugation. E) PRP gel pellet. F): Shaving the skin of rat anterior limbs. G) Skin and muscle wound. H) Suturing the skin after filling the wound of right limb with PRP and the left limbs are left without treatment.

\section{Collection of tissue samples for histological examinations}

The animals were anaesthetized by intraperitoneal injection of sodium thiopental $(40 \mathrm{mg} / \mathrm{kg} \text { of body weight })^{[28]}$, then they were sacrificed and muscle specimens of both control and experimental groups were taken after 2, 7 and 14 days of induction of injury. Specimens of all groups were fixed in $10 \%$ neutral buffered formalin for 48 hours, washed in phosphatebuffered saline(PBS), dehydrated in ascending grades of alcohol, cleared in xylene then embedded in paraffin to prepare paraffin blocks. Serial longitudinal and transverse sections of the muscles of 5 micron thickness were obtained then mounted on glass slides, deparaffinized in xylene and stained with Haematoxylin and eosin (H\&E), Mallory trichrome(MT) ${ }^{[29]}$ and immunohistochemical stain with Anti -MyoD, Anti- CD34 and Anti- TGF $\beta 1$ in muscles tissue using avidin-biotin -peroxidase complex $(\mathrm{ABC})$ techniques $^{[30]}$.

\section{Immunohistochemical technique}

Strept-avidin-biotin-peroxidase complex procedure was used to localize MyoD, CD34 and TGF- $\beta 1$. Paraffin skeletal muscles sections were deparaffinized in xylene, rehydrated, rinsed in tap water and embedded in 3\% $\mathrm{H} 2 \mathrm{O} 2$ in phosphate buffer solution (PBS) for $10 \mathrm{~min}$ to block endogenous peroxidase. Antigen retrieval in trypsin was used before detection of CD34. Sections were then incubated overnight at $4{ }^{\circ} \mathrm{C}$ with the respective primary antibodies; a monoclonal mouse anti-MyoD (Clone 5.2F, Code No ab16148, Abcam, San Francisco, CA, USA at a concentration 1-2 $\mu \mathrm{g} / \mathrm{ml}$ ), a goat polyclonal antiCD34 (Sigma Aldrich Chemie Corporation laboratories, Germany, catalogue ID SAB4300690 at $15 \mu \mathrm{g} / \mathrm{ml}$ ready to use ) and a monoclonal rabbit anti-TGF $\beta 1$ antibody (Clone TB21, MCA797, Serotec, Oxford, UK) at 1:200 dilution. The sections were incubated with the appropriate secondary antibody; a biotinylated anti-mouse IgG. Incubation of sections in horseradish peroxidase-avidin biotin complex (Vectastain Elite, Vector, CA) for 30 min at room temperature were done then 3, 3'-diaminobenzidine in $\mathrm{H} 2 \mathrm{O} 2$ (D DAB kit, Vector, CA) was added to visualize the reaction as a brown colored product in the nuclei and sometimes in the cytoplasm in case of anti- MyoD and in the cytoplasm in case of anti-CD34 and ant-anti-TGF $\beta 1$ antibodies. Sections were then counterstained with Hematoxylin and mounted. Negative control sections were obtained by the same steps of staining but with exclusion of the primary antibodies.

\section{Morphometric study}

Number of regenerating skeletal muscle fibers (identified by their characteristic central nuclei) were counted from H\&E stained sections $(\times 400)$, area $\%$ of collagen fibers deposition in the skeletal muscle tissue were measured from MT stained sections $(\times 400)$, number of immunopositive MyoD cells, number of blood vessels and area $\%$ of TGF $\beta 1$ immunoexpression were measured from anti-MyoD, anti-CD34 \& anti-TGF $\beta 1$ immunostained sections respectively (number of blood vessels $\times 200$ and the remaining 2 measures $\times 400$ ). Three none-overlapping fields/rat paraffin block sections were examined (The total was 30measurements/group) and photographed using color video camera (digital camera CH- 9435 DFC 290). Photographs of the above mentioned parameters were analyzed using Leica Qwin 500 (Imaging System, Cambridge, UK) within a frame area of 293.4288 $\mu \mathrm{m} 2$. Morphometry was carried out at the Image Analysis Unit, Anatomy Department, Faculty of Medicine, Taibahu University, Al Madinah Al Monawarrah, KSA.

\section{Statistical methods}

Data were analyzed using software computer program version 22 (SPSS, Inc., Chicago, IL, USA). Shapiro-Wilk test was used to examine the distribution of normality. Quantitative parametric data (normally distributed) were presented in mean and standard deviation, while Quantitative non parametric data (not normally distributed) were presented in median and interquartile range (IQR). For quantitative parametric data, Student's t-test (Unpaired) was used to compare between two different groups while One way Analysis of Variance (ANOVA) followed by post-hoc tukey were used to compare between more than two different groups. For quantitative non parametric data, Kruskal Wallis test followed by pairwise comparisons were used to compare more than two different groups. $\mathrm{P}$ value less than 0.05 was considered statistically significant.

\section{RESULTS}

\section{Histological results}

H\&E stained transverse sections of control skeletal muscle showed polyhederal appearances of muscle fibers with acidophilic cytoplasm and peripheral oval nuclei, whereas the longitudinal sections showed multiple oval peripheral nuclei and the characteristic transverse striations (Figs.2A, B). 2-days untreated muscle showed 
area of degenerating skeletal muscle fibers with sever inflammatory cell infiltrate (ICI) which filled the area of the wound. ICI was formed of neutrophils and macrophages mixed with debris of degenerated fibers (Fig.2C). 2-days PRP treated group showed that the area of the wound was filled with PRP and surrounded with inflammatory cells. The ICI was formed of great number of neutrophils intervening between the degenerated muscle fibers which were enlarged and vacuolated (Fig.2D). 7-days untreated group showed some regenerating muscle fibers with central nuclei and the fibers were still intervened with numerous inflammatory cells (Fig.2E). 7-days PRP treated group showed numerous regenerating muscle fibers which were interspersed with many blood capillaries but no inflammatory cells were observed (Fig.2F). 14-days untreated muscle showed filling of the wound with collagen bundles which had different directions than those of normal skeletal fibers, are stained paler and contained flat nuclei in between (Fig.2G). 14-days PRP treated muscle showed filling of the wound with skeletal muscle fibers which had the same directions as normal ones. The newly formed myotubes appeared acidophilic with multiple peripheral oval nuclei (Fig. $2 \mathrm{H}$ ).

MT stained section of control muscle showd minimal amount of collagen fibers in the connective tissue of perimysium and endomysium (Fig.3A). 2-days untreated muscle showed areas of degenerated skeletal muscle fibers with few amount of collagen (Fig.3B) whereas 2 days PRP treated group showed fewer amount of collagen fibers at the site of injury (Fig.3C). 7 days untreated group showed marked amount of collagen fibers in the area of regeneration (Fig.3D). On the other hand, 7-days PRP treated group contained fewer amount of collagen among the regenerating muscle fibers when compared with the untreated ones (Fig.3E). In 14-days untreated muscle, healing of the wound by marked deposition of collagen fibers forming fibrous tissue scar was observed (Fig.3F) whereas in 14 days PRP treated muscle, the newly formed myotubes bundles were seen separated by CT septa containing mild amount of collagen fibers (Fig.3G).

Anti-Myo D immunostained sections of control group exhibited negative MyoD immunoreaction (Fi.4A). 2-days untreated muscle fibers showed positive MyoD immunoreaction detected in many satellite cells under the sarcolemma of degenerated skeletal muscle fibers(Fig.4B). On the other hand, numerous MyoD positive satellite cells were observed in the area of degenerated skeletal muscle fibers in 2-days PRP treated ones (Fig.4C). 7-days untreated group showed many MyoD immunopositive satellite cells among the regenerating fibers (Fig.4D) whereas 7 days PRP treated group showed more numerous MyoD immunopositive satellite cells (Fig.4E) when compared to the untreated group. At 14-days, the untreated muscle showed apparent decrease in the number of MyoD positive satellite cells among the few newly formed irregular myotubes (Fig.4F) whereas a scares number of MyoD immunopostive cells were detected in the apparently normal newly formed myotubes in PRP treated muscle (Fig.4G).

Anti-CD34 immune stained control skeletal muscle fibers showed CD34 positive immune reaction in the endothelial cells of blood vessels (Fig.5A): At 2 days of injury, the untreated muscle showed mild increase in CD34 imunopositive blood vessels detected in the area of necrosis and inflammation(Fig.5B), whereas 2 days PRP treated group showed numerous newly formed CD34 immunopositive blood vessels (Fig.5C). In 7 days untreated group, few number of CD34 immunopositive blood capillaries were observed among the regenerating muscle cells (Fig.5D) whereas 7 days PRP treated group showed more numerous CD34 positive blood capillaries (Fig.5E) when compared to the untreated one 14 days untreated muscle showed very few capillaries among very few newly formed less developed myotubes (Fig.5F) whereas 14 days PRP treated muscle showed more capillaries among the numerous newly formed myotubes (Fig.5G).

Anti-TGF $\beta 1$ immunostained control skeletal muscle fibers exhibited a negative TGF $\beta 1$ immunoreaction (Fig.6A). 2 days untreated muscle fibers showed positive TGF $\beta 1$ immunoreaction which was detected in the inflammatory cells and the degenerated fibers (Fig.6B). On the other hand, few cells which exhibited TGF $\beta 1$ immuno-positivity were observed in 2days PRP treated group (Fig. 6C). 7-days untreated group exhibited strong TGF $\beta 1$ immunoreaction which was detected in patchy areas in the cytoplasm of regenerating fibers and also by many fibroblast and inflammatory cells among them. (Fig. D), whereas the 7-days PRP treated group showed faint TGF $\beta 1$ immunoreaction in the regenerating fibers and few cells among them (Fig. 6E). At the 14th day of injury, the untreated muscle showed very strong TGF $\beta 1$ immunoreaction which was exhibited as patchy areas in the cytoplasm of the newly formed myotubes, in addition to mild reaction which was observed in the cells of fibrous tissue in between (Fig.6F). On the other hand, 14-days-PRP treated muscle showed nearly negative TGF $\beta 1$ immunoreaction in the newly formed myotubes except for few positive adjacent fibroblast (Fig.6G).

\section{Statistical and Morphometric results}

In the present work, a highly significant increase in the mean number of regenerating fibers was detected in 7 days PRP treated group $(22.03 \pm 4.08)$ when compared to the untreated one $(10.13 \pm 2.15), \mathrm{P} \leq 0.001$ (Table 1$)$.

In 2-days groups, the mean area $\%$ of collagen fibers deposition showed non significant changes between control (2.50 \pm 0.49$)$, untreated $(2.75 \pm 0.45)$ and PRP treated group $(2.27 \pm .0 .59)$. At 7 days, a significant increase was observed in untreated group $(7.50 \pm 0.94)$ when compared toPRP treated $(3.68 \pm 0.72)$ and control 
$(2.50 \pm 0.49)$ ones whreas a significant increase was still observed in untreated group (10.56 2 2.24) when compared to PRP treated $(4.76 \pm 0.82)$ and control groups $(2.50 \pm 0.49)$ at 14 days of injury (Table 2$)$.

The median of number of MyoD immunopositive cells showed a significant increase in 2 days untreated group; 24 (20-28) when compared to control ; $1(0.00-2)$, and also in PRP treated group ;72 (62-78) when compared to untreated one. At 7 days, a significant increase was observed in PRP treated groups; 28 (22-33) when compared to untreated; 17 (15-20) and control ones. On 14 days, a non significant increase was observed in PRP treated group; 4(3-5) when compared to untreated; 3(2-4)and control groups (Table 3).

Regarding the mean number of blood vessels; at 2 days, PRP treated group (10.10 2.73$)$ showed a significant increase when compared to control

Table 1: Number of regenerating fibers/HPF (7 days group)

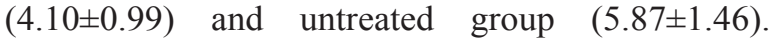
At 7 days, the increase was still significant when PRP treated group $(10.83 \pm 2.46)$ was compared to untreated $(8.47 \pm 1.17)$ and control rats. At 14 days; a significant increase was still observed in PRP treated group $(8.30 \pm 2.35)$ when compared to untreated group $(6.83 \pm 1.51)$ and control groups (Table 4).

A significant increase in the median of area $\%$ of TGF- 31 immunoexpression was noticed at 2 days untreated group ; 8.17(7.0-9.60) when compared to control ; $0.45(0.20-0.70)$ and PRP treated groups; 5 (4.20-5.70). At 7 days, a significant increase was still observed in untreated groups; $12.75(10.80-14.20)$ when compared to PRP treated one; 2.50 (2.10-3.50) and control group. At 14 days; a significant increase was observed in untreated group; 15.75(14.10-17.30) when compared to PRP treated group; 2.30 (1.60-3.20) and control one (Table 5)

\begin{tabular}{cccc}
\hline & & \\
& Untreated group & PRP treated group & $<0.001^{*}$ \\
Mean & 10.13 & 22.03 & \\
\pm SD & 2.15 & 4.08 & \\
\hline
\end{tabular}

SD: standard deviation $\quad$ P: Probability *: significance $<0.05$

Test used: Student's t-test (Unpaired)

Table 2: Area\% of collagen fibers deposition in the studied groups

\begin{tabular}{|c|c|c|c|c|c|c|c|c|}
\hline & & $\begin{array}{l}\text { Control } \\
\text { group }\end{array}$ & $\begin{array}{c}\text { Untreated } \\
\text { group }\end{array}$ & $\begin{array}{l}\text { PRP treated } \\
\text { group }\end{array}$ & $\mathrm{P}$ & P1 & $\mathrm{P} 2$ & P3 \\
\hline \multirow{2}{*}{2 days } & Mean & 2.50 & 2.75 & 2.27 & 0.23 & 0.18 & 0.24 & 0.19 \\
\hline & $\pm \mathrm{SD}$ & .49 & .54 & .59 & & & & \\
\hline \multirow{2}{*}{7 days } & Mean & 2.50 & 7.50 & 3.68 & $<0.001 *$ & $<0.001^{*}$ & $<0.001 *$ & $<0.001 *$ \\
\hline & $\pm \mathrm{SD}$ & .49 & .94 & .72 & & & & \\
\hline \multirow{2}{*}{14 days } & Mean & 2.50 & 10.56 & 4.76 & $<0.001 *$ & $<0.001^{*}$ & $<0.001^{*}$ & $<0.001^{*}$ \\
\hline & $\pm \mathrm{SD}$ & .49 & 2.24 & .82 & & & & \\
\hline
\end{tabular}

SD: standard deviation $\quad$ P: Probability *: significance $<0.05$

Test used: One way ANOVA followed by post-hoc tukey

P1: significance between Control and Untreated groups

P2: significance between Control and Treated groups

P3: significance between Untreated and Treated groups

Table 3: Number of MyoD immunopositive cells in the studied groups

\begin{tabular}{|c|c|c|c|c|c|c|c|c|}
\hline & & $\begin{array}{l}\text { Control } \\
\text { group }\end{array}$ & $\begin{array}{l}\text { Untreated } \\
\text { group }\end{array}$ & $\begin{array}{l}\text { PRP treated } \\
\text { group }\end{array}$ & $\mathrm{P}$ & $\mathrm{P} 1$ & P2 & P3 \\
\hline \multirow{2}{*}{2 days } & Median & 1.00 & 24.00 & 72.00 & $<0.001 *$ & $<0.001^{*}$ & $<0.001^{*}$ & $<0.001^{*}$ \\
\hline & IQR & $.00-2.00$ & $20.00-28.00$ & $62.00-78.00$ & & & & \\
\hline \multirow{2}{*}{7 days } & Median & 1.00 & 17.00 & 28.00 & $<0.001 *$ & $<0.001^{*}$ & $<0.001^{*}$ & $<0.001^{*}$ \\
\hline & IQR & $.00-2.00$ & $15.00-20.00$ & $22.00-33.00$ & & & & \\
\hline \multirow{2}{*}{14 days } & Median & 1.00 & 3.00 & 4.00 & $<0.001 *$ & $<0.001^{*}$ & $<0.001 *$ & 0.6 \\
\hline & IQR & $.00-2.00$ & $2.00-4.00$ & $3.00-5.00$ & & & & \\
\hline
\end{tabular}

IQR: interquartile range $P$ : Probability *: significance $<0.05$

Test used: Kruskal Wallis test followed by pairwise comparisons

P1: significance between Control and Untreated groups

P2: significance between Control and Treated groups

P3: significance between Untreated and Treated groups 
Table 4: Number of blood vessels/HPF in the studied group

\begin{tabular}{|c|c|c|c|c|c|c|c|c|}
\hline & & $\begin{array}{l}\text { Control } \\
\text { group }\end{array}$ & $\begin{array}{l}\text { Untreated } \\
\text { group }\end{array}$ & $\begin{array}{l}\text { PRP treated } \\
\text { group }\end{array}$ & $\mathrm{P}$ & $\mathrm{P} 1$ & $\mathrm{P} 2$ & $\mathrm{P} 3$ \\
\hline \multirow{2}{*}{2 days } & Mean & 4.10 & 5.87 & 10.10 & $<0.001$ & $<0.001$ & $<0.001$ & $<0.001$ \\
\hline & $\pm \mathrm{SD}$ & .99 & 1.46 & 2.73 & & & & \\
\hline \multirow{2}{*}{7 days } & Mean & 4.10 & 8.47 & 10.83 & $<0.001$ & $<0.001$ & $<0.001$ & $<0.001$ \\
\hline & $\pm \mathrm{SD}$ & .99 & 1.17 & 2.46 & & & & \\
\hline \multirow{2}{*}{14 days } & Mean & 4.10 & 6.83 & 8.30 & $<0.001$ & $<0.001$ & $<0.001$ & $<0.004$ \\
\hline & $\pm \mathrm{SD}$ & .99 & 1.51 & 2.35 & & & & \\
\hline
\end{tabular}

SD: standard deviation $\quad$ P: Probability *: significance $<0.05$

Test used: One way ANOVA followed by post-hoc tukey

P1: significance between Control and Untreated groups

P2: significance between Control and Treated groups

P3: significance between Untreated and Treated groups

Table 5: Area percent of TGF-ß1 immunoexpression in the injured skeletal muscle of the studied groups

\begin{tabular}{|c|c|c|c|c|c|c|c|c|}
\hline & & $\begin{array}{l}\text { Control } \\
\text { group }\end{array}$ & $\begin{array}{l}\text { Untreated } \\
\text { group }\end{array}$ & $\begin{array}{l}\text { PRP treated } \\
\text { group }\end{array}$ & $\mathrm{P}$ & $\mathrm{P} 1$ & $\mathrm{P} 2$ & P3 \\
\hline \multirow{2}{*}{2 days } & Median & .45 & 8.17 & 5.00 & $<0.001^{*}$ & $<0.001 *$ & $<0.001^{*}$ & $<0.001 *$ \\
\hline & IQR & $.20-.70$ & $7.40-9.60$ & $4.20-5.70$ & & & & \\
\hline \multirow{2}{*}{7 days } & Median & .45 & 12.75 & 2.50 & $<0.001 *$ & $<0.001 *$ & $<0.001^{*}$ & $<0.001^{*}$ \\
\hline & IQR & $.20-.70$ & $10.80-14.20$ & $2.10-3.50$ & & & & \\
\hline \multirow{2}{*}{14 days } & Median & .45 & 15.75 & 2.30 & $<0.001 *$ & $<0.001 *$ & $<0.001^{*}$ & $<0.001 *$ \\
\hline & IQR & $.20-.70$ & $14.10-17.30$ & $1.60-3.20$ & & & & \\
\hline
\end{tabular}

IQR: interquartile range $\quad \mathrm{P}$ : Probability *: significance $<0.05$

Test used: Kruskal Wallis test followed by pairwise comparisons.

P1: significance between Control and Untreated groups.

P2: significance between Control and Treated groups.

P3: significance between Untreated and Treated groups.

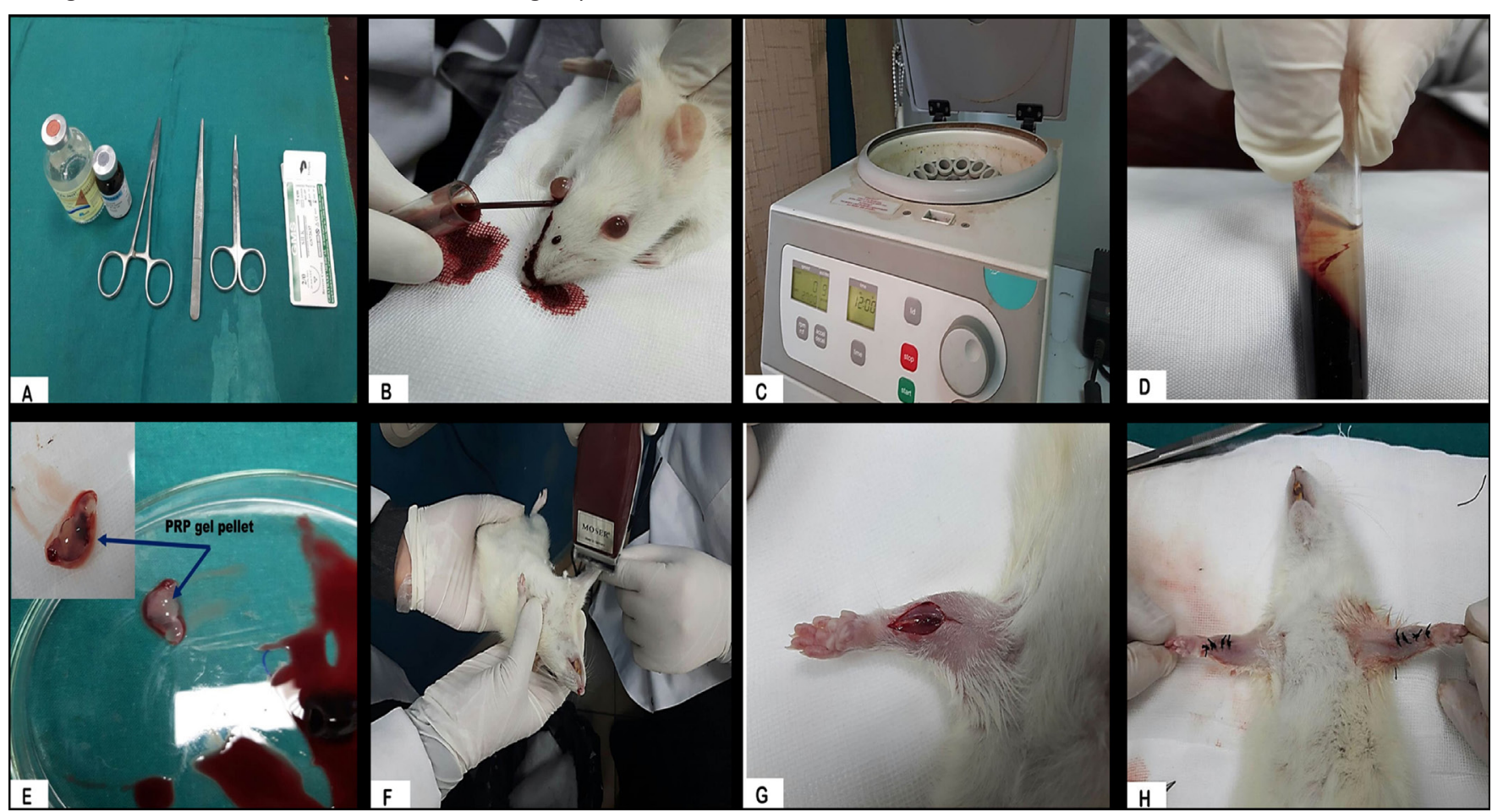

Fig. 1: A photograph shows the steps of induction of muscle injury and PRP preparation A) Surgical instruments. B) Retro-orbital blood collection. C) Centrifugation of blood samples. D) PRP-in the top layer after centrifugation. E) PRP gel pellet. F): Shaving the skin of rat anterior limbs. G) Skin and muscle wound. H) Suturing the skin after filling the wound of right limb with PRP and the left limbs are left without treatment. 


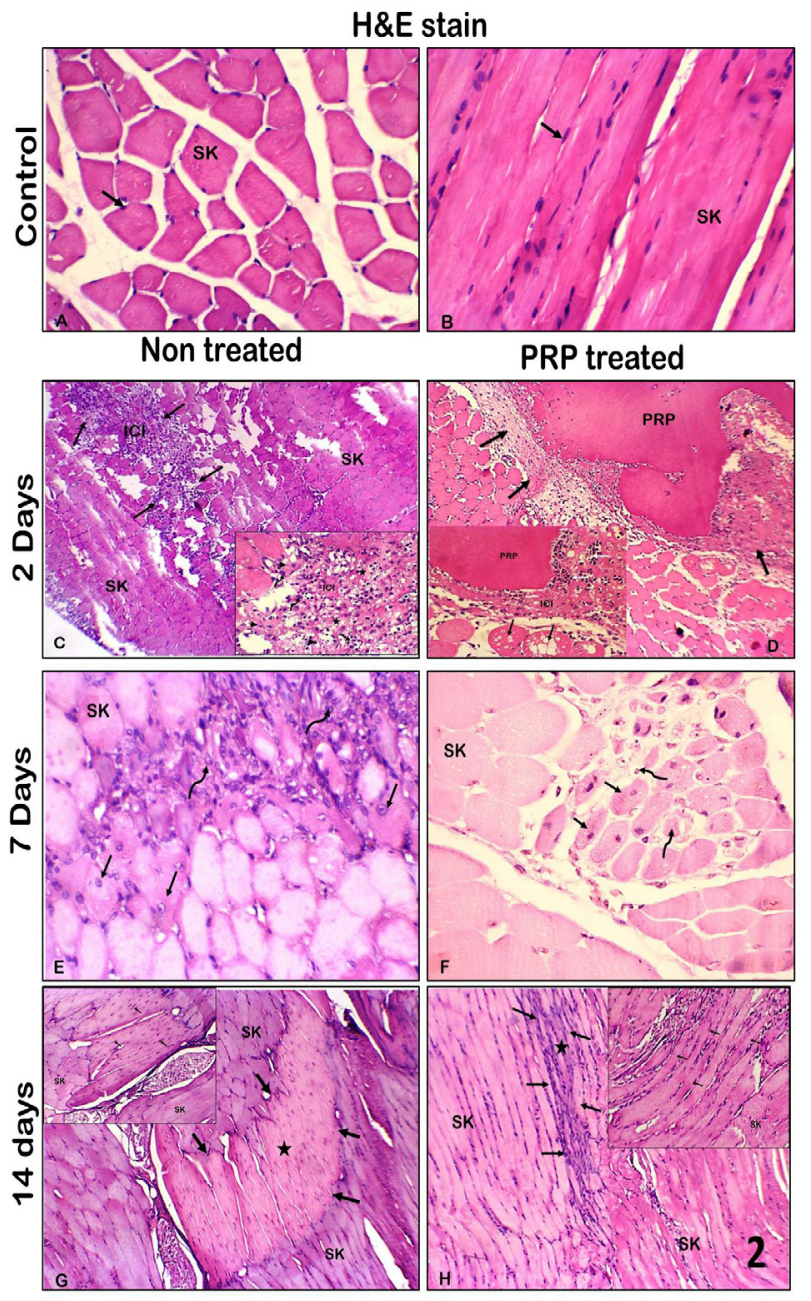

Fig. 2: A photomicrograph of H\&E stained; A) Transverse section of control group shows polyhedral appearance of skeletal muscle fibers (SK) with acidophilic cytoplasm and peripheral oval nuclei (arrow). B) Longitudinal section of skeletal muscle (SK) of control group shows multiple peripheral oval nuclei (arrow) and transverse striations. C) 2-days untreated group shows area of degenerating skeletal muscle fibers (SK) with sever inflammatory cell infiltrate (ICI) which fill the wound (arrows). Inset: ICl is formed of neutrophils (arrows) and macrophages (curved arrows) mixed with debris (star) of degenerated fibers (arrowheads). D) 2-days PRP treated group shows that area of the wound (arrows) is filled with PRP and surrounded with inflammatory cells (arrows). Inset shows: $\mathrm{ICl}$ is formed mainly of great number of neutrophils (white arrows) and degenerated muscle fibers (black arrows) which are enlarged and show cytoplasmic vacuolations E) 7-days untreated group show some regenerating muscle fibers (arrows) with central nuclei that are still intervened with numerous inflammatory cells (curved arrows). F) 7-days PRP treated group shows numerous regenerating muscle fibers (arrows) which are interspersed with many blood capillaries (curved arrows) with no inflammatory cells. G) 14-days untreated group shows filling of the wound (arrows) with collagen bundles (star) which have different directions than that of normal skeletal fibers(SK). Inset: high power magnification of collagen bundles shows thin pale stained fibers with flat nuclei (arrows) in between. H) 14-days PRP treated group shows filling of the wound (arrows) with muscle fibers (stars) which have the same directions as normal ones (SK). Inset: newly formed acidophilic myotubes (Myt) with multiple peripheral oval nuclei (arrows).

( $H \& E$ stain; $A, B, E, F$, Inset $C$, inset $D$, inset $G$ \& inset $H \times 400$; $C, D, G \& H \times 100)$.
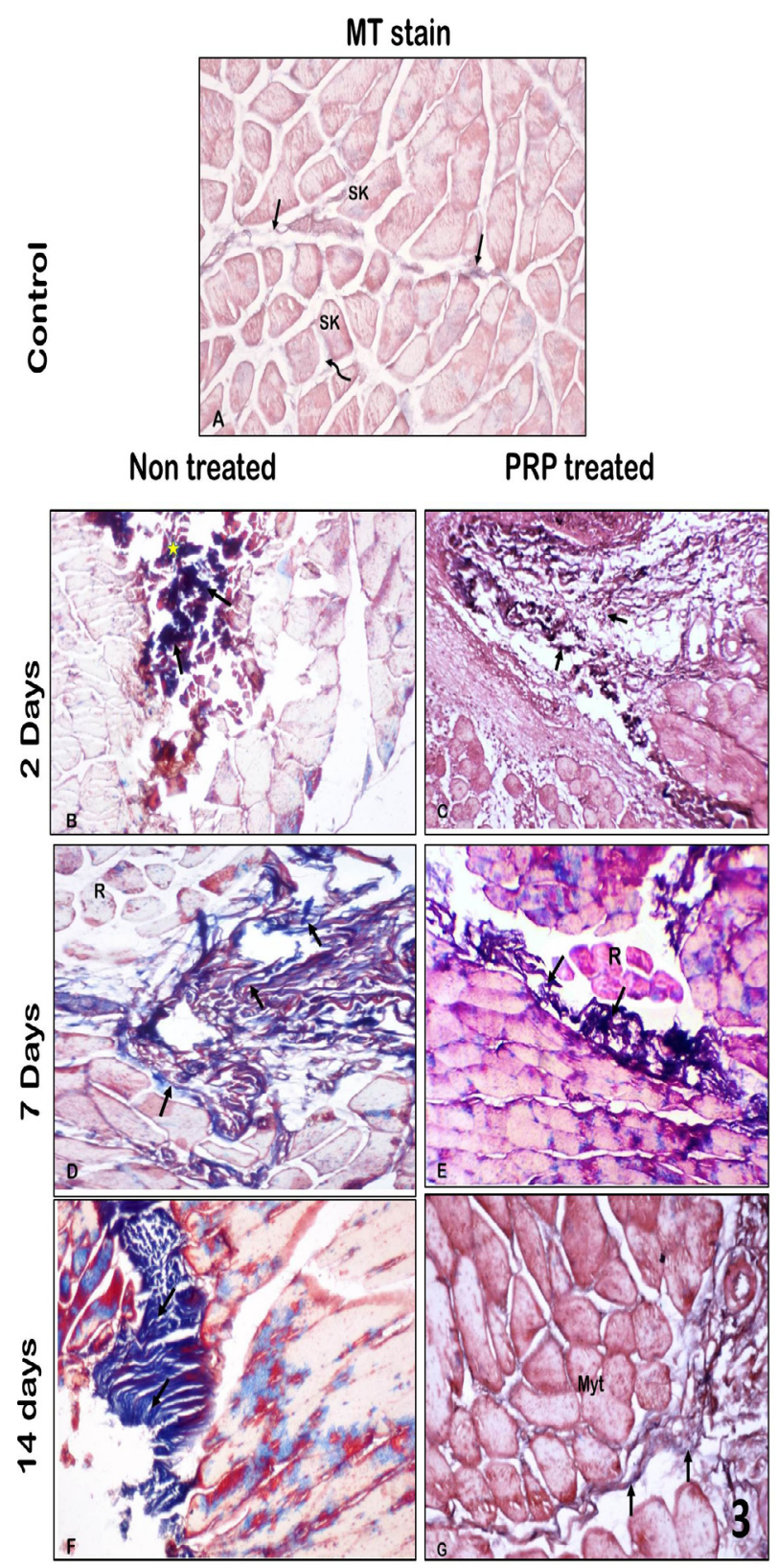

Fig. 3: A photomicrograph of A) Transverse section of control skeletal muscle (SK) shows minimal collagen fibers in the connective tissue of perimysium (arrows) and endomysium (curved arrows). B) 2-days untreated muscle shows an area of degenerated skeletal muscle fibers (star) with few amount of collagen (arrows). C) 2-days PRP treated group shows fewer amount of collagen fibers (arrows) in the region of injury. D) 7-days untreated group with marked amount of collagen fibers (arrows) in the area of regeneration (R). E) 7-days PRP treated group shows fewer amount of collagen (arrows) among the regenerating muscle fibers when compared to the untreated group (R). F) 14-days untreated muscle shows healing of the wound by marked deposition of collagen fibers forming fibrous tissue scar (arrows). G) 14-days PRP treated muscle shows newly formed myotubes bundles (Myt) which are separated by CT septa which contain mild amount of collagen fibers (arrows).

(MT stain; A, B, C, D, E, F\&G×400). 


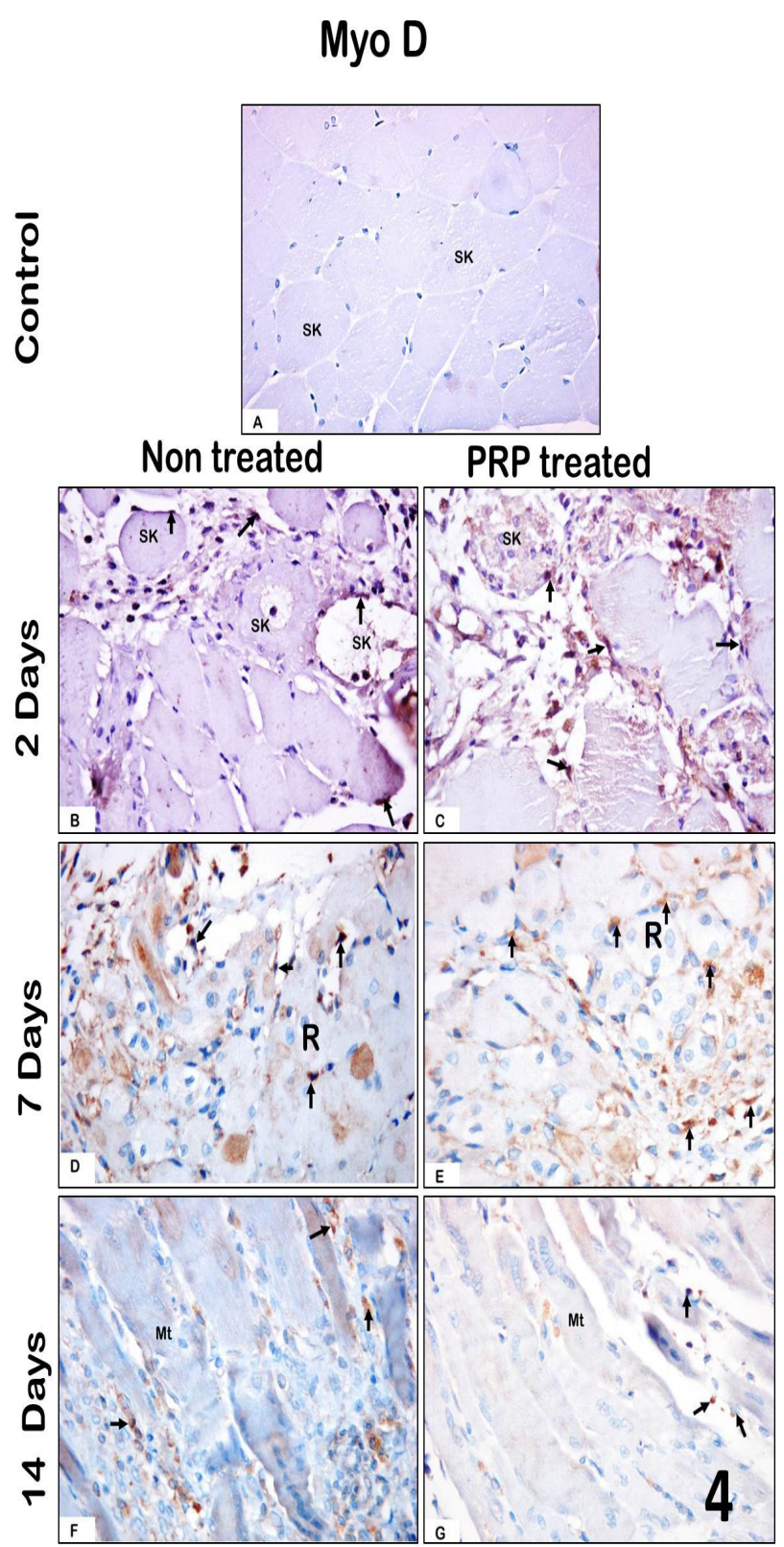

Fig. 4: A photomicrograph of A) control skeletal muscle (SK) show negative MyoD immunoreaction. B) 2-days untreated muscle fibers shows positive MyoD immunoreaction detected in many satellite cells (arrows) under the sarcolemma of degenerated skeletal muscle fibers (SK). C) 2 days PRP treated group shows numerous MyoD positive satellite cells (arrows) in the region of degenerated skeletal muscle fibers (SK). D) 7-days untreated group shows many MyoD immunopositive satellite cells (arrows) among the regenerating fibers (R). E) 7-days PRP treated group shows more numerous $\mathrm{MyoD}$ immunopositive satellite cells (arrows) among the regenerating fibers(R) when compared to untreated group. F) 14-days untreated muscle with apparent decrease in the number of MyoD positive satellite cells (arrows) among the few newly formed irregular myotubes (Myt).G) 14days PRP treated muscle shows very few MyoD positive cells (arrows) under the sarcolemma of the apparently normal newly formed myotubes (Myt).

(Anti MyoD immunostain;A,B,C,D,E,F\&G x400).

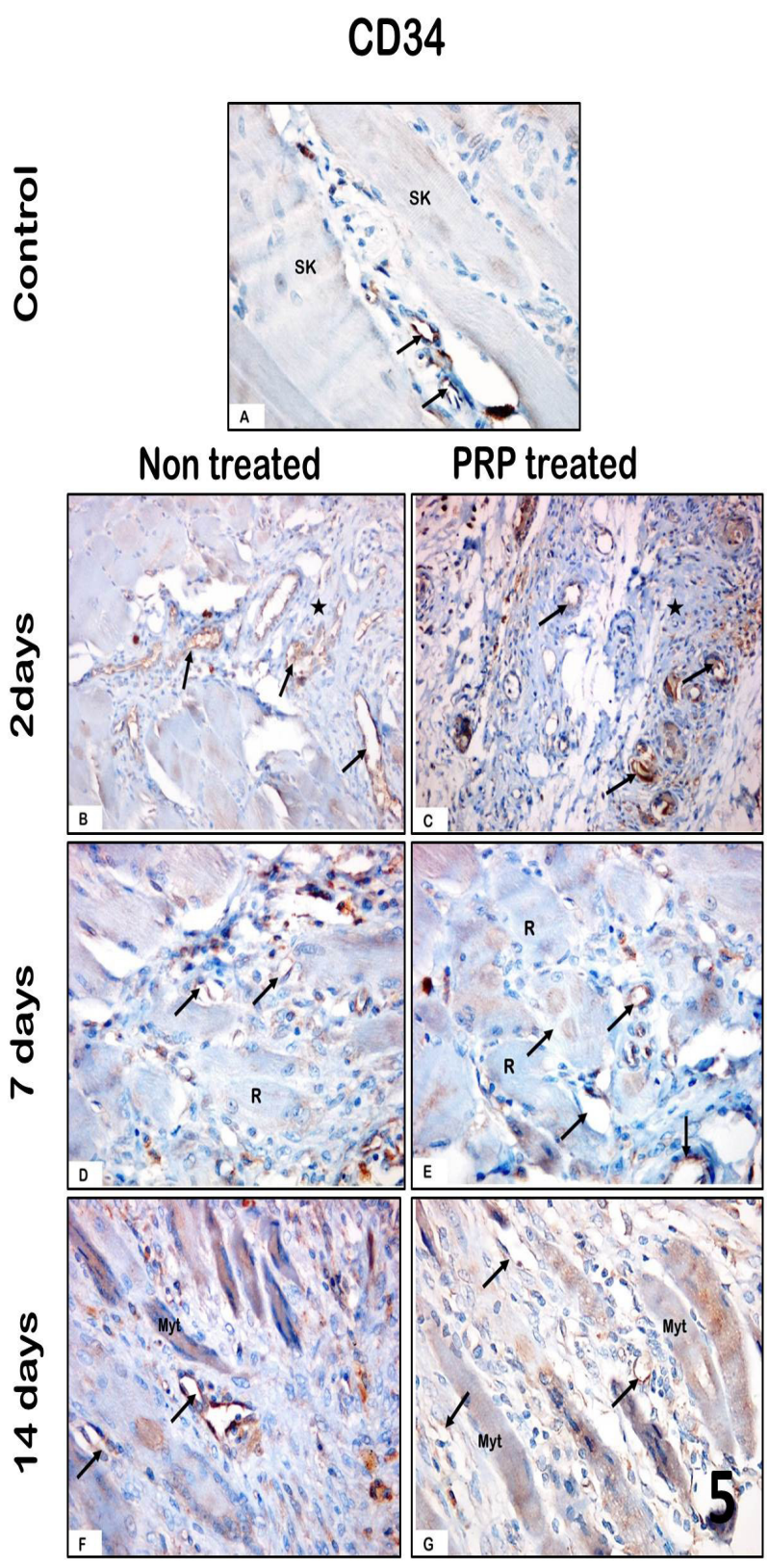

Fig. 5: A photomicrograph of: A) Control skeletal muscle fibers (SK) shows CD34 positive immunoreaction which is detected in the endothelial cells of blood vessels (arrows).B) 2-days untreated muscle fibers shows many CD34 positive blood vessels (arrows) in the area of necrosis and inflammation (star). C) 2-days PRP treated group shows numerous newly formed blood vessels (arrows) with CD 34 immunopositivity in their endothelial lining in the region (star) of degenerated fibers and inflammation. D) 7-days untreated group shows few number of blood capillaries (arrows) among the few regenerating muscle cells(R). E) 7-days PRP treated group shows more numerous CD34 immunopositive blood capillaries (arrows) among the regenerating fibers (R) when compared to untreated group. F) 14-days untreated muscle shows very few capillaries (arrows) among the very few newly formed myotubes (Myt).G) 14-days PRP treated muscle shows more capillaries (arrows) among the numerous newly formed myotubes (Myt).

(Anti CD34 immunostain; A, B, C, D, E, F\&G x400). 


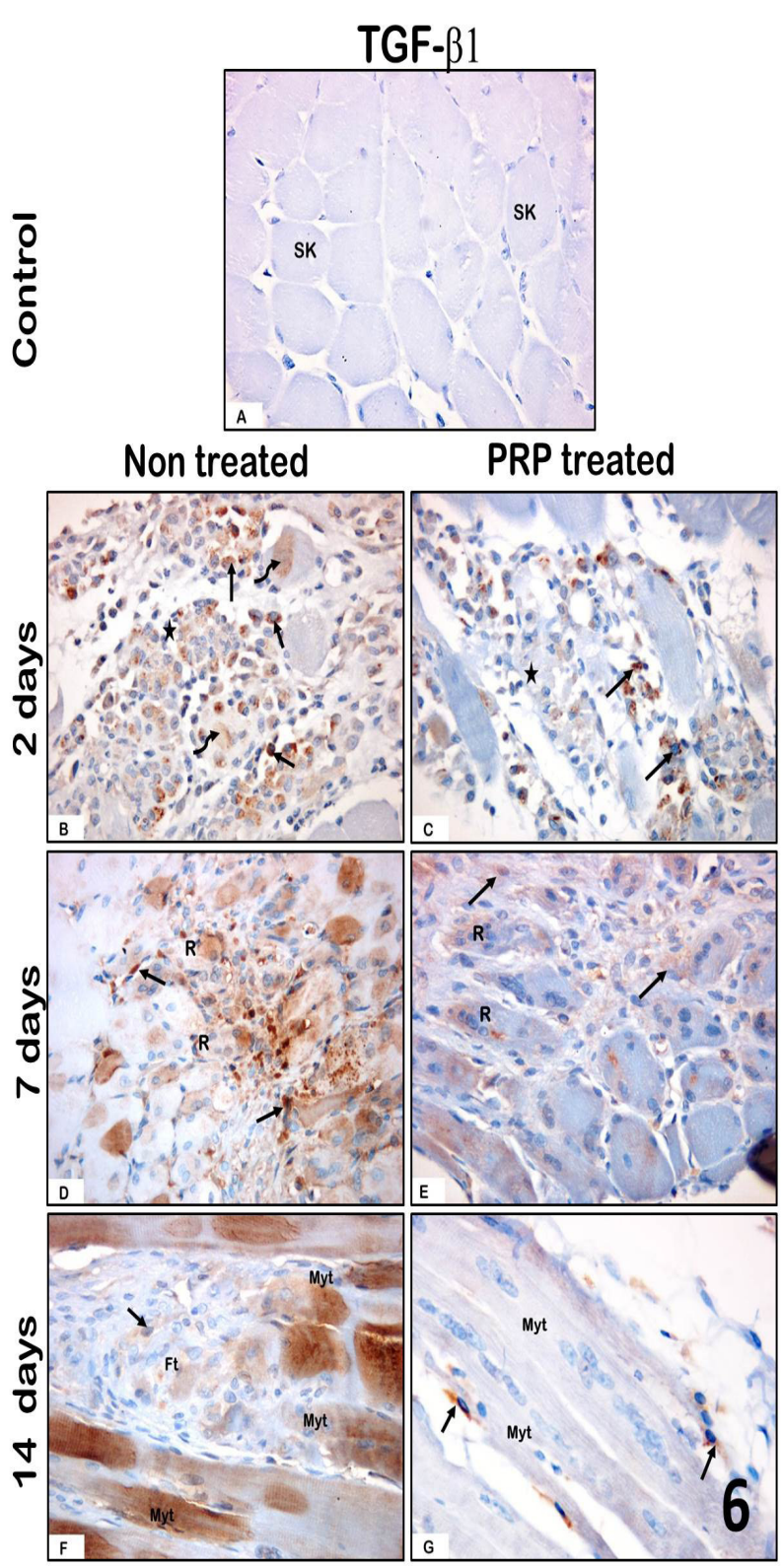

Fig. 6: A photomicrograph of: A) control skeletal muscle fibers (Sk) with negative TGF $\beta 1$ immunoreaction. B) 2 days untreated muscle fibers show positive TGF $\beta 1$ immunoreaction in the area of degeneration (star) which is detected in the inflammatory cells (arrows) and degenerated fibers(curved arrows) C) 2-days PRP treated group shows area of necrosis (star) with few cells (arrows) which exhibit TGF $\beta 1$ immunopositivity. D) 7-days untreated group shows strong patchy TGF $\beta 1$ immunoreaction which are detected in the cytoplasm of regenerating fibers $(\mathrm{R})$ and the numerous cells (arrows) mainly fibroblasts among them. E) 7-days PRP treated group shows faint TGF $\beta 1$ immunoreaction in the regenerating fibers (R) and few cells (arrows) among them. F) 14-days untreated muscle shows very strong patchy TGF $\beta 1$ immunoreaction in the cytoplasm of newly formed myotubes (Myt) and mild reaction in the cells (arrows) of fibrous tissue( $\mathrm{Ft}$ ) in between. G) 14-days PRP treated muscles shows nearly negative TGF $\beta 1$ immunoreaction in the newly formed myotubes (Myt) except for few positive adjacent fibroblasts (arrows).

(Anti TGF $\beta 1$ immunostain; A, B, C, D, E, F\&G x400).

\section{DISCUSSION}

Adult muscle tissue ability to renew in response to injury represents a vital homeostatic process. So, the need for new strategies to restore or at least speed up the process of muscle tissue regeneration presents an enormous challenge to researchers. PRP can be defined as a part of the plasma fraction of autologous blood that has a high concentration of platelet, clotting factors and some secretory proteins ${ }^{[31]}$. Autologous derived PRP is preferred to prevent possible immune reactions, intrinsic variations ${ }^{[32]}$ such as altered platelet quantity and quality caused by age, sex and preexisting patient conditions.

In the current study, 2 days after injury the skeletal muscle revealed areas of degenerating fibers with sever inflammatory cell infiltrate which was formed mainly of neutrophils and macrophages. 7 days following the injury, some regenerating muscle fibers and collagen fibers appeared, while at the 14th day of injury, marked deposition of collagen bundles and scar formation were detected. This was in agreement with the studies of Meng et al (2014) ${ }^{[33]}$ and , Criswell et al (2012) $)^{[34]}$. Interestingly, PRP administration resulted in more intense inflammatory response at the first 2 days of injury which decreased rapidly after that with a decrease in the amount of deposited collagen and appearance of numerous regenerating muscle fibers and numerous newly formed blood vessels at the site of muscle injury on the $7^{\text {th }}$ day. At the 14 th day of injury newly formed myofibers and little amount of deposited collagen fibers were observed. Järvinen et al. (2005) ${ }^{[35]}$ reported that healing process next to skeletal muscle injury is characteristically divided into three interconnected and time dependent phases including the destruction, inflammatory and reconstruction phases.

Initially in the destruction phase, a rapid necrosis, disruption of the sarcolemma and augmentation of the permeability of myofibers were observed. Then, the inflammatory phase becomes obvious within 2hours up to 3 days following muscle injury. It is defined by invasion of neutrophils and macrophages to share in phagocytosis of the debris and liberation of inflammatory cytokines. These cells reach the damaged area through the bloods stream. Therefore, if the blood supply of the injured area was damaged, regeneration cannot occur until the wound was enriched by newly formed blood vessels. Also, pro- and anti-inflammatory cytokines such as, IL-6, IL-10, IL-1b, TNFa and TGF $\beta 1$ are released. These cytokines play a key role in cell proliferation, chemotaxis and cell differentiation ${ }^{[36]}$. This highly specific inflammatory process aims to protect the basal lamina parts of the muscle fibers to be used later on as scaffolds in which the satellite cells can initiate new muscle fibers formation ${ }^{[37]}$. The repair phase includes the beginning of myofibers 
regeneration, production of a connective-tissue scar by migrating fibroblasts and neurovascular regrowth ${ }^{[35,38]}$. The end stages of muscle repair comprise maturation of the regenerated myofibers, remodeling of extracellular matrix (ECM) and restoring the contractile function of the injured muscles ${ }^{[39]}$.

In this research, PRP treatment caused an initial intense inflammatory response during the first 2 days of injury followed by its subsidence, evidenced by an apparent decrease in the inflammatory cells between the regenerated myofibers, whereas, the inflammation was also initially intense but was more persistent in the untreated groups. These findings were in agreement with the study of Harris et al.(2012) $)^{[40]}$ who injected PRP or saline solution into a variety of none injured muscle tissues of healthy rabbits and histologically evaluated the specimens after 2, 6 and 12 weeks. They reported that PRP initially promotes intensification of the inflammatory process in muscle injuries because this inflammatory phase is a very important step during muscle healing as it triggers the wound healing cascade leading to the cellular migration and proliferation, glycosaminoglycan and collagen deposition, collagen maturation and remodeling of the tissue ${ }^{[41]}$. The neutrophils and monocytes have granules filled with myeloperoxidase that contributes to the antimicrobial action of PRP ${ }^{[42]}$.

Study of Gigante et al. (2012) ${ }^{[42]}$ who used platelet-rich fibrin matrix did not detect any effect on inflammation. However, improved muscle regeneration, enhanced neovascularization and decrease of fibrosis were observed among the treated injuries $^{[40,44-46]}$. This discrepancy may be somewhat due to the different methods of PRP preparation which are not consistent and they may result in a considerable changeability in the concentrations of platelets, red blood cells, white blood cells (WBCs), and growth factors $^{[47,48]}$.

PRP as suggested by some authors modified the pattern ofinflammatory cell recruitment when compared to the observed physiological response to muscle injury. Some authors who studied wound healing reported that PRP application results in the liberation of serotonin at the injury site and subsequently reducing pain as well as the need for analgesics after surgery ${ }^{[4,50]}$. Recently, Bernuzzi et al. (2014) $)^{[51]}$ noted that ultrasound-guided injections of PRP among 53 athletes with grade I, II, and III lesions in various muscle groups resulted in a notable reduction in pain within 2 weeks of treatments and all of them regained their normal training activity within 30 days. Reduction in pain allows clinicians to prescribe lower risk analgesics with fewer drug interactions. Also, administration of autologous PRP was not associated with any signs suggestive of infection ${ }^{[52,53]}$. This may explain the antimicrobial activity of $\mathrm{PRP}^{[54]}$. Dimauro et al. (2014) ${ }^{[55]}$ reported that PRP treatment reduced the level of several apoptotic markers during muscle regeneration process. Platelets present in PRP are known as a chief source of biologically active metabolites that modulate inflammation, cellular proliferation, migration, angiogenesis, vascular remodeling, antimicrobial action and ECM synthesis ${ }^{[56]}$.

In the present research, many MyoD positive satellite cells located under the sarcolemmae of degenerated skeletal muscle fibers and among the regenerating ones were noticed at 2 and 7 days after the injury whereas initial treatment with $\operatorname{PRP}(2,7$ days $)$ caused a high significant increase in their number when compared to untreated muscles. At 14 days, few MyoD immunopostive cells were detected in untreated group. The cells were fewer in number in PRP treated groups. Muscle-specific stem cells (satellite cells) are very essential in the generation of new muscle fibers after skeletal muscle injury . They can be activated by physiological stimuli like exercise and pathological changes such as degenerative disease and muscle injury ${ }^{[57,58]}$. One of the most important factors which cause satellite cell proliferation is infiltration of the injured muscle by inflammatory cells. Proliferating satellite cells are often referred to as myogenic precursor cells (MPC) or adult myoblasts which are characterized by rapid expression of myogenic transcription factors MyoD which is extremely enhanced in activated satellite cells after injury, and is commonly regarded as a feature of satellite cells differentiation $^{[15]}$.

Interestingly, satellite cells can express myogenin and MyoD early 12 hours after injury before any visible sign of their proliferation. A lot of reports now hold up the concept that satellite cells are heterogeneous and include a subpopulation of committed satellite cells that go into the myogenic line and another one that can undergo self-renewal ${ }^{[59]}$. Absence of MyoD in activated myoblasts results only in a susceptibility for proliferation and self-renewal to maintain satellite cell pool but not differentiation, so they cannot fuse to form myotubes. Subsequent to proliferation, the greater part of satellite cells go through the myogenic differentiation program and start to fuse to the damaged myofibers or fuse together forming new myofibers ${ }^{[60]}$ which could explain the presence of very few MyoD immunopostive cells following 14 days of injury.

Hicks et al. (2016) ${ }^{[61]}$ confirmed that PRP treatment increases muscle regeneration by decreasing inflammatory infiltration, satellite cell activation and promoting angiogenesis. These findings were in agreement with result of the present work. Furthermore, earlier in vitro studies confirmed that PRP stimulated the proliferation of a variety of human cell types including mesenchymal satellite cells (MSCs) derived from bone marrow ${ }^{[62,63]}$ and adipose tissue ${ }^{[64]}$. 
Additionally, Wright Carpenter et al.(2004) ${ }^{[44]}$ found better healing of muscle injuries in mice treated with autologous conditioned serum (a form of PRP) when compared to controls. There was a significant increase in centrally nucleated large myofibers indicating regeneration. PRP also had a potent effect on the proliferation of human muscle-derived progenitor cells (hMDPCs) and keep their stemness. In addition, it maintained their multi-lineage differentiation ability which gives the cells a vast facility to differentiate into osteogenic and chondrogenic line in vitro and a myogenic line both in vitro and in vivo ${ }^{[65]}$.

PRP-treated groups showed a high significant increase in the number of CD34 positive endothelial cells lining the newly formed blood vessels when compared with the untreated groups which was more evident at 7 days of injury, consistent with Hicks et al (2016) ${ }^{[60]}$ and Jee et al (2016) ${ }^{[66]}$. Mammoto et al. (2016 ${ }^{[67]}$ reported that PRP accelerates lung regeneration since it contains abundant angiopoietin-1 which stimulates new blood vessels formation, maintains vascular integrity in vitro and in vivo and increases phosphorylation levels of lowdensity lipoprotein receptor-related protein 5 (LRP5) and thus activates angiogenic factor receptor Tie2 in endothelial cells (ECs) and accelerates endothelial cell sprouting. What's more, PRP promotes Achilles tendon healing ${ }^{[68]}$ epithelialization and angiogenesis of splitthickness skin graft donor sites ${ }^{[69]}$. Platelets directly encourage the formation of new blood vessels ${ }^{[70]}$ and their alpha granules are the principal source of PDGF which has been confirmed to participate in wound healing, angiogenesis and matrix synthesis ${ }^{[71]}$. PRP obtained via centrifugation as in the current study has higher PDGF and lower TGF-B concentrations compared to other methods like apheresis ${ }^{[72]}$.

All through current study, a significant increase in the expression of TGF $\beta 1$ by muscle tissue was observed in untreated groups when compared to PRP treated one which showed nearly negative reaction after 14 days of injury.TGF- $\beta 1$ has been found to inhibit fetal myoblasts differentiation but does not affect embryonic myoblasts. In mature adult muscle, TGF $\beta 1$ negatively affects skeletal muscle regeneration by inhibiting satellite cell proliferation and myofiber fusion. Furthermore, in abnormal muscle regeneration there is a persistent inflammatory response and over expression of TGF $\beta 1$ and myostatin which stimulate the transformation of myogenic cells into myofibroblasts with the formation of fibrotic tissue to replace damaged myofibers ${ }^{[65,73]}$. Accordingly, reducing the levels of TGF- $\beta 1$ has been proven to be beneficial for several myopathic conditions ${ }^{[74-77]}$. Combination treatment of PRP and Losartan (angiotensin II receptor blocker) reduced fibrous tissue formation and increased angiogenesis in a model of rat muscle contusion ${ }^{[78]}$. Additionally, Plasma rich in growth factors stimulates corneal wound healing and reduces haze development after photorefractive keratectomy ${ }^{[79]}$. Moreover, intradermal injection of PRP showed improvement in the degree of scars in atrophic acne ${ }^{[80]}$.

Some studies suggested that PRP could induce muscle fibrosis because of the elevated concentration of TGF $\beta 1$ stored in $\alpha$-granules of the platelets which stimulates type 1 collagen synthesis. In addition, it is an anti apoptotic mediator for myofibroblasts and may cause the differentiation of fibroblasts to activated myofibroblasts ${ }^{[81,82]}$. However our research revealed an anti-fibrotic effect of PRP supported by Sugaria et al. $(2010)^{[83]}$ who mentioned that PRP effects are contradictory concerning the development of fibrosis as they also enclose anti-fibrotic molecules, hepatocyte growth factor (HGF) and serum amyloid protein which could inhibit the fibrosis and regulate macrophage function in different models. Such discrepancy could be explained by the multiple PRP preparations that were used. Besides, variation may also results from patient differences in age, medical conditions (particularly hematologic diseases) and healing capacities. Accordingly, the effects of PRP are influenced by significant differences in the content of platelet preparations as well as personal uniqueness which probably contributes to its inconsistent findings in the text.

\section{CONCLUSION AND RECOMMENDATIONS}

PRP could exert a promising effect on skeletal muscle injuries via enhancement of myogenesis, neovasularization and by exertion of anti-fibrotic effect. Therefore, PRP may be a valuable product to be applied in the management of skeletal muscle injuries. Therefore, further studies are needed to find out different mechanisms which are involved in the special actions of PRP, uses and adverse effects.

\section{CONFLICT OF INTEREST}

There are no conflicts of interest.

\section{REFERENCES}

1. Croisier JL, Forthomme B, Namurois MH, Vanderthommen M, CrielaardJM.Hamstring muscle strain recurrence and strength performance disorders. Am J Sports Med 2002; 30: 199-203.

2. WoolfAD, Pfleger B. Burden of major musculoskeletal conditions. Bull World Health Organ 2003; 81:646, 656 .

3. Verrall G M, Slavotinek J P, Barnes PG, Fon GT, Spriggins AJ . Clinical risk factors for hamstring muscle strain injury: a prospective study with correlation of injury by magnetic resonance imaging. Br J Sports Med 2001; 35: 435-440. 
4. Orchard J, Best T. The management of muscle strain injuries: an early return versus the risk of recurrence. Clin J Sport Med 2002; 12: 3-5.

5. Fukushima K, Badlani N, Usas A, Riano F, Fu F, Huard $\mathbf{J}$. The use of an antifibrosis agent to improve muscle recovery after laceration. Am J Sports Med 2001; 29: 394-402.

6. Day CS, Buranapanitkit B, Riano FA, Tomaino MM, Somogyi G, Sotereanos DG, Kuroda R, Huard J. Insulin growth factor-1 decreases muscle atrophy following denervation. Microsurgery 2002; 22: 144151.

7. Paoni NF, Peale F, Wang F, Errett Baroncini C, Steinmetz H, Toy K, Bai W, Williams M, Bunting S, Gerritsen ME ,Powell Braxton L . Time course of skeletal muscle repair and gene expression following acute hind limb ischemia in the mouse. Physiol Genomics 2002;11: 263-272

8. Prisk V, Huard J. Muscle injuries and repair: the role of prostaglandins and inflammation. Histol. Histopathol. 2003 ; 18:1243-1256.

9. Ten Broek RW, Grefte S, Von den Hoff JW. Regulatory factors and cell populations involved in skeletal muscle regeneration. Journal of cellular physiology $2010 ; 224: 7-16$

10. Mourkioti F and Rosenthal N. IGF-1, inflammation and stem cells: interactions during muscle regeneration. Trends Immunol 26:2005 535-542.

11. Chargé SBP, Rudnicki MA. Cellular and molecular regulation of muscle regeneration. Physiol Rev 2004; 84: 209-38.

12. Karalaki M, Fili S, Philippou A, Koutsilieris M. Muscle regeneration: cellular and molecular events. In Vivo. 2009; 23:779-96.

13. Collins CA, Zammit PS, Ruiz AP, Morgan JE, Partridge TA .A population of myogenic stem cells that survives skeletal muscle aging. Stem Cells 2007; 25: $885-894$.

14. Yoseph B, Soker S. Redefining the satellite cell as the motor of skeletal muscle regeneration. J Sci Appl 2015; 3: 76-82.

15. Kanisicak O, Mendez JJ, Yamamoto S, Yamamoto M, Goldhamer DJ. Progenitors of skeletal muscle satellite cells express the muscle determination gene, MyoD. Dev Biol 2009; 332:131-141.

16. Dedkov EI, KostrominovaTY,Borisov AB, Carlson BM. MyoD and myogenin protein expression in skeletal muscles of senile rats. Cell Tissue Res 2003; 311: 401-416.
17. Le Grand F, RudnickiMA .Skeletal muscle satellite cells and adult myogenesis. Curr Opin Cell Biol 2007; 19:628-633.

18. Cervelli V, Gentile P, Scioli MG, Grimaldi M, Casciani CU, Spagnoli LG, Orlandi A. Application of platelet-rich plasma in plastic surgery: clinical and in vitro evaluation. Tissue Eng Part C Methods 2009; 15: 625-634.

19. Kazakos K, Lyras DN, Verettas D, Tilkeridis K, Tryfonidis M. The use of autologous PRP gel as an aid in the management of acute trauma wounds. Injury 2009; 40: 801-805.

20. Mishra A1, Velotta J, Brinton TJ, Wang X, Chang S, Palmer O, Sheikh A, Chung J, Yang PC, Robbins R, Fischbein M. Reva Ten platelet rich plasma improves cardiac function after myocardial injury. Cardiovase Revasc Med 2010; 12:158-63.

21. Yu W, Wang J, Yin J . Platelet-rich plasma: a promising product for treatment of peripheral nerve regeneration after nerve injury. Int J Neurosci 2011; 121(4):176-80.

22. Kaux JF, Crielaard JM .Platelet-rich plasma application in the management of chronic tendinopathies. Acta Orthop Belg 2013; 79: 10-5.

23. Marx RE . Platelet-rich plasma: evidence to support its use. J Oral Maxillo fac Surg 2004; 62: 489-496.

24. Anitua E, Prado R, Sánchez M, Orive G. Plateletrich plasma: preparation and formulation. Oper Tech Orthop 2012; 22:25- 32.

25. Mosca MJ1, Rodeo SA . Platelet-rich plasma for muscle injuries: game over or time out? Curr Rev Musculoskelet Med 2015;8:145-153.

26. Borrione P, Grasso L, Chierto E, Geuna S, Racca S, Abbadessa G, Ronchi G, Faiola F, Di Gianfrancesco A, Pigozzi F. (2014) Experimental model for the study of the effects of platelet-rich plasma on the early phases of muscle healing. Blood Transfus 2014; 12: s221-8.

27. Hoff J. Methods of Blood Collection in the Mouse. Lab Animal ,2000; 29:47-53.

28. Toblli JE, Cao G, Oliveri L, Angerosa M. Comparison of oxidative stress and inflammation induced by different intravenous iron su- crose similar preparations in a rat model. Inflamm Allergy Drug Targets 2012; 11: 66-78.

29. Bancroft AD, Gamble M. Theory and Practice of histological techniques, 6th ed. Churchill Livingstone, Philadelphia; 2008.

30. Hsu SM, Raine L, Fanger H. Use of avidin-biotinperoxidase complex $(\mathrm{ABC})$ in immunoperoxidase 
techniques: a comparison between $\mathrm{ABC}$ and unlabeled antibody (PAP) procedures. J Histochem Cytochem 1981; 29:577-580.

31. Simman R, Hoffmann A, Bohinc RJ ,Peterson WC, Russ AJ . Role of platelet-rich plasma in acceleration of bone fracture healing. Ann Plast Surg 2008; 61:33744.

32. Weibrich G, Kleis WK, Hafner G, Hitzler WE. Growth factor levels in platelet-rich plasma and correlations with donor age, sex, and platelet count. J Cranio maxilla fac Surg 2002; 30: 97-102.

33. Meng J, Zou X, Wu R, Zhong R, Zhu D, Zhang Y. Accelerated regeneration of the skeletal muscle in RNF13-knockout mice is mediated by macrophagesecreted IL-4/IL-6.Protein Cell 2014; 5:235-247.

34. Criswell TL, Corona BT, Ward CL, Miller M, Patel M, Wang Z, Christ GJ, Soker S. Compression-Induced Muscle Injury in Rats That Mimics Compartment Syndrome in Humans. Am J Pathol 2012; 184:222536 ?

35. Järvinen TAH, Järvinen TLN, Kääriäinen M, Kalimo H, Järvinen M. Muscle injuries. Am J Sports Med 2005 33:745-64.

36. Collins CA, Zammit PS, RuizAP, Morgan JE, Partridge TA. A population of myogenic stem cells that survives skeletal muscle aging. Stem Cells 2007; 25: 885-894.

37. Hurme T, Kalimo H. Activation of myogenic precursor cells after muscle injury. Med Sci Sports Exerc 1992; 24: 197-205.

38. Tidball JG. Inflammatory processes in muscle injury and repair. Am J PhysiolRegulIntegr Comp Physiol 2005; 288:R345-53.

39. Carosio S, Berardinelli MG, Aucello M, Musaro A. Impact of ageing on muscle cell regeneration. Ageing Res Rev 2009; 10:35-42.

40. Harris NL, Huffer WE, Von Stade E, Larson AI, Phinney S, Purnell ML. The effect of platelet-rich plasma on normal soft tissues in the rabbit. J Bone Joint Surg Am 2012; 94:786-93.

41. Everts PA, Hoogbergen MM, Weber TA, Devilee RJ, van Monftort G, de Hingh IH. Is the use of autologous platelet-rich plasma gels in gynecologic, cardiac, and general, reconstructive surgery beneficial? Curr Pharm Biotechnol 2012; 13:1163-72.

42. Kon E, Filardo G, Di Martino A, Marcacci M. Plateletrich plasma (PRP) to treat sports injuries: evidence to support its use. Knee Surg Sports TraumatolArthrosc 2011; 19:516-27.
43. Gigante A, Del Torto M, Manzotti S, Cianforlini M, Busilacchi A, Davidson PA, Greco F, MattioliBelmonte M . Platelet rich fibrin matrix effects on skeletal muscle lesions: an experimental study. Journal of Biological Regulators and Homeostatic Agents 2012, 26:475-484.

44. Wright-Carpenter T1, Opolon P, Appell HJ, Meijer H, Wehling P, Mir LM . Treatment of muscle injuries by local administration of autologous conditioned serum: animal experiments using a muscle contusion model. Int J Sports Med 2004; 25:582-7.

45. Hammond JW, Hinton RY, Curl LA, Muriel JM, Lovering RM. Use of autologous platelet-rich plasma to treat muscle strain injuries.. Am J Sports Med 2010; $37(6): 1135-42$.

46. Bubnov R, Yevseenko V, Semeniv I. Ultrasound guided injections of Platelets Rich Plasma for muscle injury in professional athletes: comparative study. Med Ultrason 2013; 15(2):101-5.

47. Castillo TN, Pouliot MA, Kim JH, Dragoo JL. Comparison of growth factor and platelet concentration from commercial platelet rich plasma separation systems. Am J Sports Med 2011; 39:266-71.

48. Mazzocca AD1, McCarthy MB, Chowaniec DM, Cote MP, Romeo AA, Bradley JP, Arciero RA, Beitzel K. Platelet-rich plasma differs according to preparation method and human variability. J Bone Joint Surg 2012; 94: 308-16.

49. Foster TE, Puskas BL, Mandelbaum BR, GerhardtMB, Rodeo SA . Platelet-rich plasma: from basic science to clinical applications. Am J Sports Med 2009; 37:2259-72.

50. Carter MJ, Fylling CP, Parnell, LKS. Use of platelet rich plasma gel on wound healing: a systematic review and meta-analysis. Eplasty 2011; 11:382-410.

51. Bernuzzi G, Petraglia F, Pedrini MF, De Filippo M, Pogliacomi F, Verdano MA, Costantino C . Use of platelet-rich plasma in the care of sports injuries: our experience with ultrasound-guided injection. Blood Transfus 2014; 12(1):229-34.

52. Kazakos K, Lyras DN, Verettas D, Tilkeridis K, Tryfonidis M. The use of autologous PRP gel as an aid in the management of acute trauma wounds. Injury 2009; 40: 801-805.

53. Malavolta EA, Gracitelli MEC, Sunada EE, Benegas E, Prada FS, Bolliger Neto R, Rodrigues MB, Ferreira Neto AA, Camargo OP . Platelet-rich plasma in arthroscopic repairs of complete tears of the rotator cuff. Rev Bras Ortop 2012; 47:741-7. 
54. Yuan T, Zhang CQ, Wang JHC. Aumenting tendon and ligament repair with platelet-rich plasma (PRP). Muscles Ligaments Tendons J 2013; 3:139-49.

55. Dimauro I, Grasso L, Fittipaldi S, Fantini C, Mercatelli N, Racca S, Geuna S, Di Gianfrancesco A, Caporossi D, Pigozzi F, Borrione P. Platelet-Rich Plasma and Skeletal Muscle Healing: A Molecular Analysis of the Early Phases of the Regeneration Process in an Experimental Animal Model . PLoS One 2014; 23:e102993.

56. Mosca MJ1, Rodeo SA . Platelet-rich plasma for muscle injuries: game over or time out? Curr Rev Musculoskelet Med 2015; 8:145-153.

57. Wen, Y, Bi P, Liu W, Asakura A, Keller C, Kuang S. Constitutive notch activation upregulates pax 7 and promotes the self-renewal of skeletal muscle satellite cells. Mol Cell Biol 2012; 32: 2300-2311.

58. Brzoska, E, Ciemerych MA, Przewozniak M, Zimowska M. Regulation of muscle stem cells activation: The role of growth factors and extracellular matrix. Vitam Horm 2011; 87: 239-276.

59. Rocheteau P, Gayraud Morel B, SieglCachedenier I, Blasco M A, Tajbakhsh S .A subpopulation of adult skeletal muscle stem cells retains all template DNA strands after cell division. Cell 2012; 148: 112-125.

60. Yin H, Price F, Rudnicki MA. Satellite Cells and the Muscle Stem Cell Niche Physiol Rev 2013; 93: 23-67.

61. Hicks JM,Li H, Philippon MJ, Hurwitz SR, Huard J, Hogan MV.Customized Platelet-Rich Plasma for Skeletal Muscle Injuries. Orthop J Sports Med 2016; 4: $2325967116 \mathrm{~S} 00143$.

62. Parsons P1, Butcher A, Hesselden K, Ellis K, Maughan J, Milner R, Scott M, Alley C, Watson JT, Horner A . Platelet rich concentrate supports human mesenchymal stem cell proliferation, bone morphogenetic protein-2 messenger RNA expression, alkaline phosphatase activity, and bone formation in vitro: a mode of action to enhance bone repair. J Orthop Trauma 2008; 22: 595-604.

63. Zaky SH, Ottonello A, Strada P, Cancedda R, Mastrogiacomo M. Platelet lysate favours in vitro expansion of human bone marrow stromal cells for bone and cartilage engineering. J Tissue Eng Regen Med 2008; 2: 472-481.

64. Kocaoemer A, Kern S, Kluter H, Bieback K .Human $\mathrm{AB}$ serum and Thrombin activated platelet-rich plasma are suitable alternatives to fetal calf serum for the expansion of mesenchymal stem cells from adipose tissue. Stem Cells 2007; 25: 1270-1278.

65. Li H1, Usas A, Poddar M, Chen CW, Thompson S, Ahani B, Cummins J, Lavasani M, Huard J. Platelet-
Rich Plasma Promotes the Proliferation of Human Muscle Derived Progenitor Cells and Maintains Their Stemness .PLOS One 2013; 8: e64923.

66. Jee CH , Eom NY, Jang HM , Jung HW, Choi ES , Won JH1, Hong IH , Kang BT , Jeong DW , Jung DI . Effect of autologous platelet-rich plasma application on cutaneous wound healing in dog. J Vet Sci 2016; 17: 79-87.

67. Mammoto T, Chen Z, Jiang A, Jiang E, Ingber DEMammoto A. Acceleration of Lung Regeneration by Platelet-Rich Plasma Extract through the LowDensity Lipoprotein Receptor-Related Protein 5-Tie2 Pathway. Am J Respir Cell Mol Biol 2016; 54:103-13.

68. Lyras DN, Kazakos K, Verettas D, Polychronidis A, Tryfonidis M, Botaitis S, Agrogiannis G, Simopoulos C, Kokka A, Patsouris E. The influence of plateletrich plasma on angiogenesis during the early phase of tendon healing. Foot Ankle Int 2009; 30:1101-6.

69. Kakudo N, Kushida S, Minakata T, Suzuki K, Kusumoto K. Platelet-rich plasma promotes epithelialization and angiogenesis in a split thickness skin graft donor site. Med Mol Morphol 2011; 44:233-6.

70. Kurita J, Miyamoto M, Ishii Y, Aoyama J, Takagi G, Naito Z, Tabata Y, Ochi M, Shimizu K .Enhanced vascularization by controlled release of plateletrich plasma impregnated in biodegradable gelatin hydrogel. Ann thoracsurg 2011; 92(3):837-844.

71. Reigstad LJ, Varhaug JE, Lillehaug J. Structural and functional specificities of PDGF-C and PDGF-D, the novel members of the platelet-derived growth factors family. The FEBS J 2005; 272:5723-5741.

72. Weibrich G, Kleis WK, Hafner G, Hitzler WE, Wagner W. Comparison of platelet, leukocyte, and growth factor levels in point-of-care platelet-enriched plasma, prepared using a modified curasan kit, with preparations received from a local blood bank. Clin Oral Implants Res 2003; 14:357-62.

73. Burks TN, Cohn RD. Role of TGF $\beta$ signaling in inherited and acquired myopathies. Skelet Muscle 2011; 4:19.

74. Bedair HS, Karthikeyan T, Quintero A, Li Y, Huard J. Angiotensin II receptor blockade administered after injury improves muscle regeneration and decreases fibrosis in normal skeletal muscle. Am J Sports Med 2008; 36:1548-1554.

75. Taniguti AP, Pertille A, Matsumura CY, Santo Neto $\mathrm{H}$, Marques MJ. Prevention of muscle fibrosis and myonecrosis in mdx mice by suramin,a TGF-beta1 blocker. Muscle Nerve 2011; 43:82-87.

76. Nozaki M, Li Y, Zhu J, Ambrosio F, Uehara K, Fu FH, Huard J. Improved muscle healing after contusion 
injury by the inhibitory effect of suramin on myostatin, a negative regulator of muscle growth. Am J Sports Med 2008; 36:2354-2362.

77. Carlson ME, Conboy MJ, Hsu M, Barchas L, Jeong J, Agrawal A, MikelsAJ,Agrawal S, Schaffer DV, Conboy IM. Relative roles of TGF-betal and Wnt in the systemic regulation and aging of satellite cell responses. Aging Cell 2009; 8:676-689.

78. Terada ST K, Mifune Y, Takayama K, Lee S, Gharaibeh B, Otsuka T, Fu FH, Huard J . Use of an antifibrotic agent improves the effect of platelet-rich plasma on muscle healing after injury. J Bone Joint Surg Am 2013; 95:980-8

79. Anitua E1, Muruzabal F, Alcalde I, Merayo-Lloves J, Orive G. Plasma rich in growth factors (PRGFEndoret) stimulates corneal wound healing and reduceshaze formation after PRK surgery. Exp Eye Res 2013; 115:153-61
80. Nofal E, Helmy A, Nofal A, Alakad R, Nasr M Platelet-rich plasma versus CROSS technique with $100 \%$ trichloroacetic acid versus combined skin needling and platelet rich plasma in the treatment of atrophic acne scars: a comparative study. Dermatol Surg 2014; 40:864-73.

81. Lech M, Anders HJ . Macrophages and fibrosis: how resident and infiltrating mononeuclear phagocytes orchestrate all phases of tissue injury and repair Biochim Biophys Acta 2013; 1832:989-9738.

82. Sampson S, Gerhardt M, Mandelbaum B. Platelet rich plasma injection grafts for musculoskeletal injuries: A review. Curr Rev Musculoskelet Med 2008; 1:165-74.

83. Sugiura T, Kawaguchi Y, Soejima M , Katsumata Y, Gono T , Baba S , Kawamoto M , Murakawa Y, Yamanaka H , Hara M .Increased HGF and c-Met in muscle tissues of polymyositis and dermatomyositis patients: beneficial roles of HGF in muscle regeneration. Clin Immunol 2010; 136:387-99. 


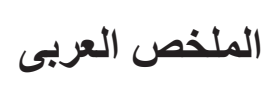

البلازما الأتية الغتية بالصفائح الاموية تحفزاظهار الخلايا النجمية لبروتين

العضلات دى، وتؤدى الى تكوين الأوعية الاموية ولها تأثير مضاد للتليف

فى فأر التجارب كمثال للاصابات الجرحية للعضلات الهوبن الهيكلية

غالية محفوظ عطية2،1،، هدى عاطف1، رشا أحمد المنسي3

1قسم علم الأنسجة وبيولوجيا الخلية، كلية الطب، جامعة المنصورة، المنصورة، مصر.

2قسم التشريح، كلية الطب، جامعة طيبة، المدينة المنورة، المملكة العربية السعودية.

3قسم علم التثريح وعلم الأجنة، كلية الطب، جامعة عين شمس، القاهرة، مصر.

المقدمة: تشكل إصابات العضلات الهيكلية الجزء الأكبر من الإصابات الرياضية ذات الصلة. وقد شجع دور عوامل النمو في شفاء الأنسجة المصابة على استخدام البلازما الغنية بالصفائح الدموية الهرف: در اسة تأثثر البلازما الغنية بالصفائح الدموية على إصابة العضلات الهيكلية. المواد و الأساليب: نم تقسيم أربعين جرذا من الذكور البالغين إلى أربع مجموعات منساوية كالاتى :المجموعة الضابطة

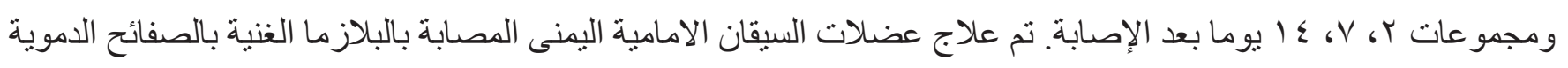

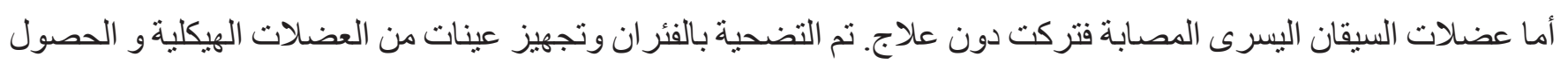

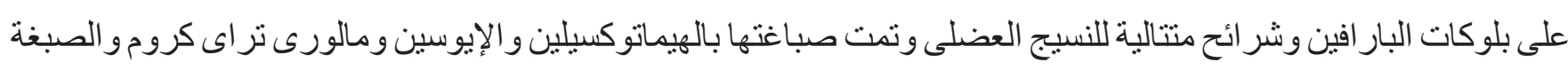
المناعية الكيميائية للكثف عن بروتين العضلات دى، وCD34 و TGFß1 وتبع ذللك إجر اء در اسة مورفومترية. النتائج: تسبب العلاج بالبلازما الغنية بالصفائح الدموية فى استجابة التهابية اولية مكثفة فى نسيج العضلات مع تسلل خلايا البلاعم و النيتروفيل و النتي هدأت بعد ذلك في اليوم السابع من الإصابة. وبالمقارنة مع المجموعات غير المعالجة فقد أظهرت نتائج

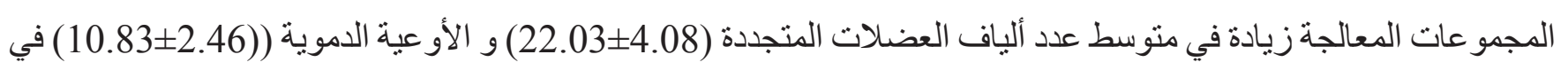
اليوم السابع وزيادة فى متوسط عدد الخلايا النجمية المظهرة لبروتين العضلات دى بعد يومين 72 (78-62) وفي اليوم السابع كانت 28(22-33) لتصبح غير ذيى دلالة بعد ـ ا يوما 4(5-3). وقد لوحظ انخفاضا كبير ا فى متوسط النسبة المئوية لترسب

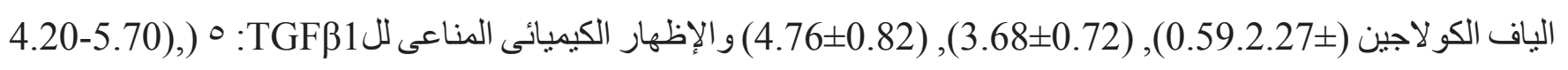

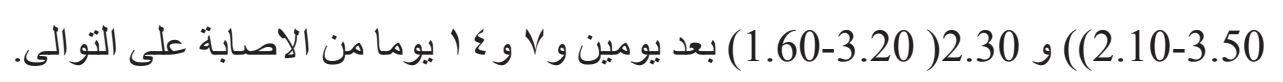

الاستتتاج: لاستخدام البلازما الذاتية الغنية بالصفائح الدموية نأثير ا واعد على إصابات العضلات الهيكلية عن طريق زيادة تكوين ألألياف العضلية والأو عية الدموية والحد من التليف. وحيث أن مشتقات الدم الذاتية آمنة، قد يكون استخدام البلازما الغنية بالصفائح الدموية منتج ذات قيمة لتطبيقها فى مثل هذه الإصابات. 